\title{
ULTRA-ESTRUTURA DAS GLÂNDULAS ANEXAS AO FERRĀO DE Camponotus rufipes (FABRICIUS) (HYMENOPTERA - FORMICIDAE) *
}

\author{
VARDECI GAMA \\ Departamento de Ciências Biológicas da Universidade Federal de São Carlos, \\ 13.560 São Carlos, S.P.
}

e

CARMINDA DA CRUZ LANDIM

Departamento de Morfologia, Instituto de Biociências, UNESP, 13.500 Rio Claro, S.P.

\begin{abstract}
SUMMARY
The sting glands of Camponotus rufipes are well developed and formed by an acid and a basic gland. The acid gland has three different regions as follows: two free filaments, a convoluted gland constituted by the twistings of the tubule resulting from the fusion of the free filaments and a reservoir. There are two types of cells present in this gland. The first type has ectodermal origin and forms the reservoir and intima, the second type is probably alsu ectodermic but forms the secretory epithelium around the free and convoluted filaments. In the free filaments the Golgi are well developed and the secretion, stored in vacuoles, has low density. The secretion is collected from the secretory cell canalicules, originated from the intima, which percolate cavities on the secretory cells. In the convoluted gland the secretion results from mitochondrial transformation.

The basic gland is originated entirely from ectoderm. In the ants observed were apparently in a degenerative phase.
\end{abstract}

\section{$R E S U M O$}

As glândulas anexas ao ferrão de Camponotus rufipes sãu bem desenvolvidas e compostas de uma glândula ácida com três regiões distintas: dois filamentos livres, uma região convoluta formada por um tubo resultante da união dos dois filamentos, extremamente dobrado e um reservatório, e além desta uma glândula básica em forma de saco bífido. A ultra-estrutura dessas glândulas mostrou que a glândula ácida apresenta células de origem ectodérmica que formam o reservatório e uma intima que coleta a secreção das células secretoras que formam um epitélio em torno dos filamentos livres e túbulo convoluto. As células secretoras, provavelmente também de origem ectodérmica, têm maior atividade na regiāo livre dos filamentos, onde o Golgi é muito desenvolvido e secreção de baixa densidade eletrônica se acumula em vacúolos. A secreção é coletada por canalículos que se

- Financiado pela FAPESP - Fundação de Amparo à Pesquisa do Estado de São Paulo (Biol. 75/0221). 
originam na intima e percorrem cavidades resultantes da invaginação de sua membrana plásmica, providas de microvilosidades. Na porção convoluta, a "secreção" presente, parece se originar de modificações dos mitocôndrios.

A glândula básica é também de origem ectodérmica. Nas formigas estudadas acha-se provavelmente em degeneração.

\section{INTRODUÇÃO}

As glândulas anexas ao ferrão dos himenópteros têm sido muito estudadas; no caso particular das formigas numerosos trabalhos têm sido publicados ultimamente, dos quais interessa-nos o de Hermann e Blum (1968) que trata da morfologia do aparelho de veneno de Camponotus pennsylvanicus e o de Hermann (1969) que traça as tendências evolutivas em três sub-famílias estreitamente relacionadas.

A morfologia do ferrão e suas glândulas foi estudada na espécie objeto da presente investigação, por Gama e cols. (1975) tendo-se verificado a presença de uma glândula ácida constituída de dois filamentos livres, que se reunem num filamento único, que logo após a origem se enrola sobre a superfície dorsal do reservatório onde acaba por desembocar. A glândula básica tem a forma de um saco bífido e desemboca próximo ao duto do reservatório da glândula ácida.

A ultra-estrutura das glândulas do ferrão, a julgar pela literatura que nos chegou às mãos, não tem sido muito investigada. Publicação de Cruz-Landim e Kitajima (1966) relata a ultra-estrutura da porção secretora da glândula ácida de Apis, mas o assunto foi melhor explorado por Ratcliffe e King (1967, 1969a, b e 1970) em Nasonia vitripennis.

As glândulas anexas ao ferrão dos himenópteros são de origem tegumental e como tal encontram muitas similares em outros insetos, embora com outras localizações e funções diferentes. No que concerne à glândula ácida, encontramos semelhanças ao nível de organização ultra-estrutural descritas em trabalhos de Happ e cols. (1966), Stein (1966 e 1967); Berry (1968); Forsyth (1970) e Suzzomi (1972), sem falar em semelhanças com algumas glândulas pertencentes ao sistema salivar dos próprios himenópteros e outros insetos, como as mandibulares e hipofaríngeas (Cruz-Landim, 1967). A semelhança consiste no fato de essas glândulas terem a porção secretora constituída de dois tipos de células das quais uma tem revestimento cuticular (célula quitinogênica de Ratcliffe e King) e envia canalículos para o interior da célula secretora.

A ultra-estrutura da glândula básica tem sido menos estudada, sendo contudo bem conhecida ao nível da microscopia óptica (Lello, 1968).

$O$ presente trabalho descreve a ultra-estrutura das glàndulas anexas ao ferrão com a finalidade de complementar o estudo anterior, citado acima.

\section{MATERIAL E MÉTODOS}

Operárias de Camponotus rufipes foram capturadas fora do formigueiro e as glândulas anexas ao ferrão dissecadas em glutaraldeído a 2,5\% em tampão fosfato. As glândulas foram posteriormente fixadas por imersão na mesma mistura 
durante 2 hs. A pós-fixação foi feita em ósmio a $1 \%$ também em tampão fosfato, contendo $5 \%$ de sacarose, por 1 h. A contrastação com uralina foi feita logo a seguir usando-se solução de acetato de uranila a $0,5 \%$ em águá distilada contendo também $5 \%$ de sacarose. Após lavagem dos especimens em tampão a desidratação foi levada a efeito em série crescente de etanóis. Para a embebição e inclusão usou-se Epon 812.

Os cortes (finos e semi-finos) foram obtidos em ultramicrótomo Porter Blum MT 2 com navalhas de vidro. Os cortes semi-finos foram utilizados para rastreamento e corados com azul de metileno-azur II, enquanto os finos foram constrastados com citrato de chumbo (Reynolds, 1963) e examinados em microscópio eletrônico Zeiss EM 9-S 2.

\section{RESULTADOS}

A morfologia das glândulas anexas ao ferrão de $C$. rufipes acha-se ilustrada na Figura 1 a. A parte livre da glândula ácida é um tubo formado por um epitélio constituido de duas camadas de células: as internas achatadas e com revestimento cuticular, e as secretoras, que envolvem as primeiras (Fig. 1 b). A glândula básica é formada por um epitélio constituído de uma única camada de células de altura irregular, apresentando cutícula revestindo a luz (Fig. 1 c).

\section{Glândula Acida}

$\mathrm{Na}$ glândula ácida pelo menos três regiões morfologicamente diferentes podem ser distinguidas Os filamentos livres (Fig. 1 a, b, e Fig. 2) apresentam ao microscópio eletrônico um aspecto que concorda com a descrição dos autores anteriores. Ao longo do lúmen há uma intima cuticular constituída de células baixas, com contatos celulares muito sinuosos e providos de desmossomos septados. Essa íntima dá origem a canais que penetram no interior das cavidades das células secretoras (Fig. 2; 3 a) para as quais estas enviam microvilosidades. As células da intima apresentam em seu citoplasma numerosas microvesículas e vacúolos pequenos contendo material denso, sob a forma de filamentos irregulares no interior (Fig. $3 \mathrm{~b}$ ).

A célula secretcra apresenta um retículo endoplasmático granular relativamente bem desenvolvido, numerosas zonas de Golgi, razoável número de mitocôndrios pequenos geralmente alongados, alguns grânulos densos, tomados por lisossomos e grandes vacúolos, aparentemente resultantes da coalescência de gotas de material de natureza provavelmente lipída (Figs. 4, 5 e 6). O Golgi apresenta-se nesta célula como estruturas curvadas em ferradura, apresentando na face convexa material denso no interior da cisterna e na face côncava acúmulo de pequenas vesículas com material menos denso. Notam-se na proximidade do Golgi alguns grânulos contendo material de densidade eletrônica média, tomados como secreção imatura, mas nenhuma relação pode ser estabelecida entre estes e as vesículas da face côncava ou os vacúolos (Fig. 5).

Na figura 6a vê-se um aspecto da porção basal da célula secretora mostrando numerosas dobras da membrana plásmica basal, que indicam possivelmente absorçāo de material de hemolinfa. Ainda nesta porção basal notam-se as gotas de 
material de densidade eletrônica extremamente baixa de cuja fusão provavelmente se originam os grandes vacúolos da porção apical. Nota-se que nesta zona o material aparentemente acha-se rodeado por cisternas do retículo rugoso. As vesículas pequenas estão aí presentes também.

Depois da união dos filamentos livres em um único filamento, este se dobra numerosas vezes sobre a parede do reservatório onde acaba por desembocar, tormando a chamada glândula convoluta (Fig. 1a). Ao microscópio eletrônico verifica-se que a célula intimal sofre grandes transformações nesta porção. Em primeiro lugar a cutícula que reveste o lúmen se espessa grandemente, depois a altura da célula aumenta e caracteristicamente passa a apresentar na sua porção apical numerosos canalículos e vesículas indicativas da atividade absorvente (Figs. 7 e 8). Na cutícula distingue-se agora nitidamente a epicutícula e a endocuticula. Entre os canais e vesiculas de absorção notam-se numerosos microtúbulos (Fig. 8b). Além destes elementos a célula intimal é pobre em orgânulos, apresentando um núcleo com cromatina difusa, alguns ribossomos e derivados lisossômicos (Fig. 8 a e b).

A célula secretora também se modifica. Na sua porção basal encontramos agora numerosas dobras da membrana associadas a mitocôndrios, bem como reticulo dilatado contendo material de baixa densidade (Fig. 9 a). Em seu citoplasma aparecem mitocôndrios grandes com matriz muito densa (Fig. 9 b) que aparentemente se transformam em secreção.

A fixação destạ região da glândula, bem como a infiltração é muito difícil, o que prejudicou a obtenção de bons cortes nesta parte da glândula ácida. Contudo, pode-se observar que os mitocôndrios podem perder suas cristas passando a constituir grânulos homogêneos de densidade relativamente alta (Fig. 8 a) e que no interior do conteúdo destes grânulos pode surgir material cristalino (Figs. 10 a e b). A célula secretora ainda apresenta cavidades para as quais microvilosidades se projetam, contudo, apesar de material eletrondenso ser observado na base de microvilosidade (Fig. 10 a) e no interior da cavidade, a presença de canalículo coletor não foi vista, o que aliás é coerente com o aspecto da intima nesta região.

O reservatório apresenta-se como um saco de paredes muito finas, constituído ao que parece apenas por células correspondentes à intima (Fig. $10 \mathrm{c}$ ), nas quais a cuticula mostra-se ainda mais espessa. Algumas fibras musculares formam uma trama frouxa na superficie do reservatório.

\section{Glândula Básica}

A glândula básica apresenta-se como um epitélio de uma única camada de células limitando um lúmen bastante grande, para onde são eliminados e armazenados os produtos de sua atividade secretora. Este epitélio secreta uma cutícula que reveste a luz. Externamente ao epitélio a glândula apresenta musculatura que forma uma capa descontínua (Fig. 11 a e b). A musculatura é estriada como se observa na Figura $11 \mathrm{~b}$.

Caracteristicamente a glândula básica das formigas examinadas apresentou suas células com sinais típicos de degeneração. Apesar do núcleo apresentar-se 
com a cromatina pouco condensada (caracteristica de atividade) o citoplasma nāo mostrou Golgi evidente, nem retículo endoplasmático diferenciado. Por outro lado mostrou grande riqueza em ribossomos livres, alguns poliribossomos e muitos mitocôndrios alongados (Fig. 12). Os mitocôndrios aparecem distribuídos por toda célula, mas os apicais se colocam logo abaixo da cutícula (Figs. 11a, 12, 13 e 14a) tomando às vezes posições perpendiculares a ela e associando-se com invaginações dilatadas da membrana plásmica (Figs. 12 e 14a). Essas invaginações aprofundam-se bastante na célula, aparecendo no citoplasma como túbulos contendo material de baixa densidade (Fig. 12) ainda associados a mitocôndrios. A matriz dos mitocôndrios tem alta densidade. Os mitocôndrios desta célula apresentam-se muito plásticos, havendo várias evidências morfológicas de que se curvam para envolver porções de citoplasma (Figs. 12 e 13c). Há também evidência de que alguns sofram alterações passando a constituir outras estruturas como se pode observar na Figura 13a e c.

As células da glândula básica mostram-se muito ricas em grânulos densos de tamanhos variados (Figs. 11, 12, 13 e 14). Parece certo que se trata de lisossomos em várias fases de atividade (lisossomos primários, secundários e corpos residuais). Os corpos residuais aperecem enormes, contendo lamelas concêntricas no interior, além de material cristalino (Fig. 14 b). Parecem ser resultantes da fusāo de vários lisossomos secundários, mas não está afastada a possibilidade de os mitocôndrios tomarem parte em sua formação como parece indicar a figura 13a e b.

As membranas divisórias deste epitélio são muito sinuosas (Fig. 13 a) apresentando desmossomos septados ao longo de sua extensão e uma zona de adesão na parte apical (Fig. 13 b).

\section{DISCUSSÃO E CONCLUSÕES}

A morfologia das glândulas anexas ao ferrão pode ser bem estudada no material examinado, ficando claro que a glândula ácida apresenta-se constituída de dois tipos de células, provavelmente da mesma origem embriológica. A célula intimal seguramente é de origem ectodérmica e constitui-se em toda extensão da glândula num canal responsável pela coleta, transporte e armazenamento da secreção, sendo o reservatório apenas um alargamento deste canal e os canalículos coletores que vão à intimidade da célula secretora, suas ramificações.

Esse tipo de constituição é comum nas glândulas epidérmicas dos insetos e. conforme discutido por Beams e Anderson (1961), embora o canal coletor pareça intracelular, ele está na realidade, colocado no espaço extracelular, formado por invaginações profundas da membrana plásmica da célula secretora que a percorrem como verdadeiros canais, para os quais se projetam microvilosidades. Ao iniciar sua penetração através desses canais, o caṇalículo coletor apresenta ainda uma cutícula espessa e citoplasma em sua constituição, mas suas extremidades apresentam cutícula porosa. Embora não tenha sido observada relação entre os eventuais produtos de secreção e os canalículos coletores, parece evidente que a via de eliminação de secreção é da célula secretora para o espaço pericanalicular. A função da intima nesta região seria então a de coletar a secreção e conduzi-la, providenciando ao mesmo tempo, uma proteção da célula secretora contra seus possiveis efeitos danosos. Não está afastada a hipótese de que a célula intimal tenha de per si alguma função secretora, na porção inicial da glândula. 
Nas formigas examinadas, as células secretoras em toda a extensão da glândula ácida não parecem especialmente ativas apesar do Golgi desenvolvido. A natureza da secreção nesta região não parece ser protéica, nem tampouco polissacarídica. A baixa densidade dos vacúolos que provavelmente a contém, e a falta de grânulos outros, indicam material muito fluido e neste caso, as microvilosidades pericanaliculares teriam eventualmente o papel de reabsorver certos componentes eliminados.

A julgar pelo aspecto morfológico a atividade da célula é diferente na porção convoluta, onde fica evidente a evolução dos mitocôndrios para formar uma eventual secreção. Blum e Hermann (1969) estudando Pogonomyrmex badius chegaram à conclusão que a porção verdadeiramente secretora da glândula ácida é a convoluta, servindo os filamentos livres para obtenção dos precursores a partir da hemolinfa. Provavelmente ainda, a julgar pelo aspecto morfológico das células, as glândulas das operárias estudadas não se achavam em fase muito ativa, talvez tratando-se de formigas já velhas; de qualquer maneira as evidências morfológicas parecem não sustentar os achados de Blum e Hermann. Os filamentos livres mostram dobras da membrana plásmica basal (Fig. $6 \mathrm{~b}$ ), que poderiam ser responsabilizadas por retirada de material da hemolinfa, mas estas são ainda mais desenvolvidas na porção convoluta, onde se acham associadas a mitocôndrios. Por outro lado, embora a glândula convoluta tenha aparentemente mais secreção nas células secretoras que o filamento terminal, a via de eliminação desta secreção não ficou clara nas micrografias examinadas, uma vez que não se detectou canalículo coletor ou qualquer outra comunicação com o lúmen do túbulo.

A função da intima também parece ser diferente na região convoluta, como evidenciado pela presença de ativa absorção.

Com base na aparência morfológica da glândula ácida parece lícito propor para os filamentos livres uma função secretora, com obtenção da matéria prima a partir da hemolinfa e, para a porção convoluta, além desta função um papel acentuado na modificação do conteúdo da luz do duto através de reabsorção ativa de material como indicam os canais e vesículas subcuticulares. A função "secretora" da região convoluta é de natureza muito diferente da usual em células secretoras, resultando a "secreçāo" aparentemente de transformação dos mitocôndrios.

No que tange à glândula básica a origem é inteiramente ectodérmica. Nesta glândula as evidências a favor da idade avançada das formigas utilizadas são maiores, ou o número de lisossomos é maior e as evidências de secreção ativa por parte da célula, menores.

Nesta fase da glândula básica os orgânulos celulares que chamam mais atenção são justamente os mitocôndrios e os lisossomos. A localização dos mitocôndrios logo abaixo da cuticula e associados a canais formados por invaginações da membrana apical, indicam transporte tivo de substâncis por estas células, provavelmente de retorno do lúmen para seu interior.

Os lisossomos indicam várias fases de autofagia celular, existindo alguns indicios de que os mitocôndrios têm participação no processo ou por fornecerem a energia necessária à digestão ou por estarem eles próprios sendo digeridos.

As células da glândula ácida apresentam alturas variáveis e membranas contactantes sinuosas. A sinuosidade da membrana bem como das estruturas funcionais aí presentes indicam que as células podem ser suieitas a distencões com aumento do conteúdo do lúmen. 
A organização ultra-estrutural das glândulas anexas ao ferrão esclarece sua origem e em parte sua função, podendo-se concluir: 1) que a glândula ácida é constituída de dois tipos de células. A camada mais interna (intima) forma $o$ reservatório e reveste a luz da porção glandular sendo de origem ectodérmica, e a mais externa (células secretoras) provavelmente é também de origem ectodérmica e estende-se até à região convoluta sobre o reservatório. Neste sentido parece óbvio que a glândula convoluta é externa ao reservatório, estando apenas dobrada sobre ele. O crescimento desta porção da glândula, que parece ter um papel secretor menor, durante a filogenese das formigas pode estar ligada ao "amadurecimento" da secreção eliminada para a luz através de um processo semelhante ao que ocorre ao longo do néfron. 2) a glândula básica tem origem ectodérmica, e sua morfologia indica função completamente diversa da da glândula ácida, inclusive com degeneração precoce.

\section{BIBLIOGRAFIA}

BEAMS, H. W., and E. ANDERSON, 1961 - Fine structure of "intracellular ductules" in certain glands of the carabid beetle. J. Morph.. 109: 159-171.

BERRY, S. J., 1968 - The fine structure of the colleterial glands of Hyalophora cecropia (lepidoptera). J. Morph., 125: 259-280.

BLUM, M. S., and H. R. HERMANN, 1969 - The hymenopterous poison gland: probable functions of the main glandular elements. J. (jeorgia Entomol. Soc., 4 (1): 23-28

CRUZ-LANDIM, C. da, e E. W. KITAJIMA, 1966. Ultraestrutura do aparelho venenifero de Apis (Hymenoptera, Apidae) Mem. Inst. Butantā. Simp. Internac. Venenos Animais, 33: $701-710$.

CRUZ-LANDIM, C. da, 1967 - Estudo comparativo de algumas glândulas das abelhas (Hymenoptera, Apoidea) e respectivas implicaçōes evolutivas. Arq. Zool. 15: 177-290.

FORSYTH, D. J., 1970 - The ultrastructure of the pygidial defence glands of the carabid Pterostichus madidus F. J. Morph., 131: 397-416

GAMA, V., O. C. BUENO e C. da CRUZ-LANDIM. $1975 \rightarrow$ O aparelho do ferrão de Camponotus rufipes (Fabricius) (Hymenoptera, Formicide) e suas estruturas anexas. Rev. Brasil. Biol., 35 (4): 589-593.

HAPP, G. M., J. D. STRANDBERG and C. M. HAPP, 1966 - The terpene-producing glands of a phasmid insect. Cell morphology and histochemistry. J. Morph., 119: 143-160.

HERMANN, H. R., 1969 - The hymenopterous poison apparatus: evolutionary trends in three closely related subfamilies of ants (Hymenoptera: Formicidae). J. Georgia Entomol. Soc., 4: 123-141

HERMANN; H. R., and M. S. BLUM, 1968 - The hymenopternus poison apparatus. VI Camponotus pennsylvanicus (Hymenoptera: Formicidae). Psyche. 75: 216-227.

HERMANN. H. R., and M. S. BLUM. 1969 - The hymenopterous poison gland: probable functions of the main glandular elements. J. Georgia Entomol. Soc.. 4: 23-28

LELLO. E., 1968 - Glânđulas anexas ao aparelho de ferrão das abelhas (Hymenoptera, Apoidea). Tese de doutoramento apresentada à Faculdade de Filosofia. Ciências e Letras de Rio Claro

RATCLIFHE, N. A., and P. E. KING, 1967. The "Venom" system of Nasonia vitripennis (Walker). (Hymenoptera: Pteromalidae). Proc. $R$. ent. Soc. London AAQ. 42: 49-61 
RATCLIFFE, N. A., and P. E. KING, 1969a. - Morphological, ultraestructural, histochemical and electrophoretic studies on the venom system of Nasania vitripennis Walke: (Hymenoptera: Pteromalidae). J. Morph., 127: 177-204

RATCLIFFE, N. A., and P E. KING, 1969b - Ultratructural in the mitochondria of the acid gland of Nosonia vitripennis (Walker) (Pteromalidae: Hymenoptera) induced by starvation. Z. Zellforsch., 99: 459-468.

RATCLIFF'E, N. A., and P. E. KING, 1970 - The effect of starvation on the fine structure of the venom system in Nasonia vitriøennis. J. Insect. Physiol.. 16: 885-903

REYNOLDS, E. S., 1963. The use of lead citrate at high pH as electron apaque stain in lectron microscopy. J. Cell. Biol., 17: 208-212.

STEIN. G.. 1966 - tiber den Feinbau der Duftdrüsen ron Feuerwanzen (Pyrrhocoris apteris L., Geocorisae). II Mitteilung. Das ábleitende Kanalsystem und die nichtdrüsigen Anteile. Z. Zellforsch., 75: 501-516.

STEIN, G., 1967 - Über den Feinbau der Duftdrüsen von Feuerwanzen (Pyrrhocoria anterus L., Geocorisae). Die 2. larvale Abdominaldrise. Z. Zelforsch., 79: 49-63.

SUZzomI, J. P., 1972 - Ultrastructure de la glande de la spermathèque chez Phosphuga atrata L. (Coleoptera Silphidae). z. Zellforsch.. 128: 426-437. 


\section{LEGENDA DAS FIGURAS}

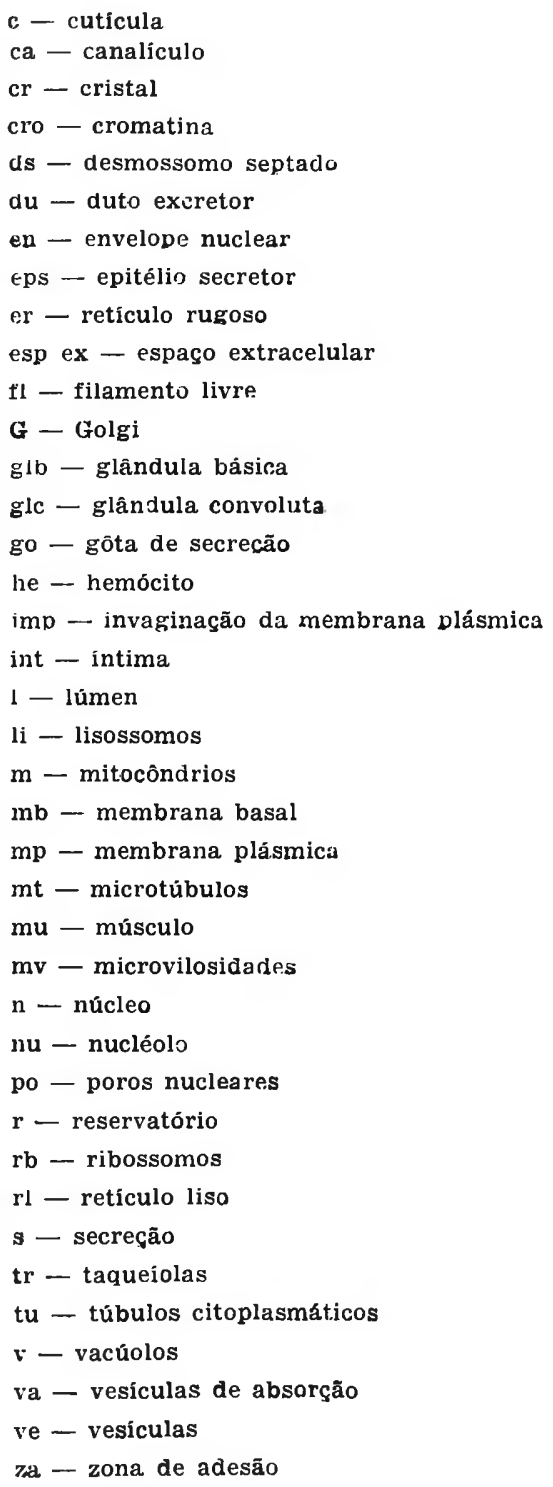



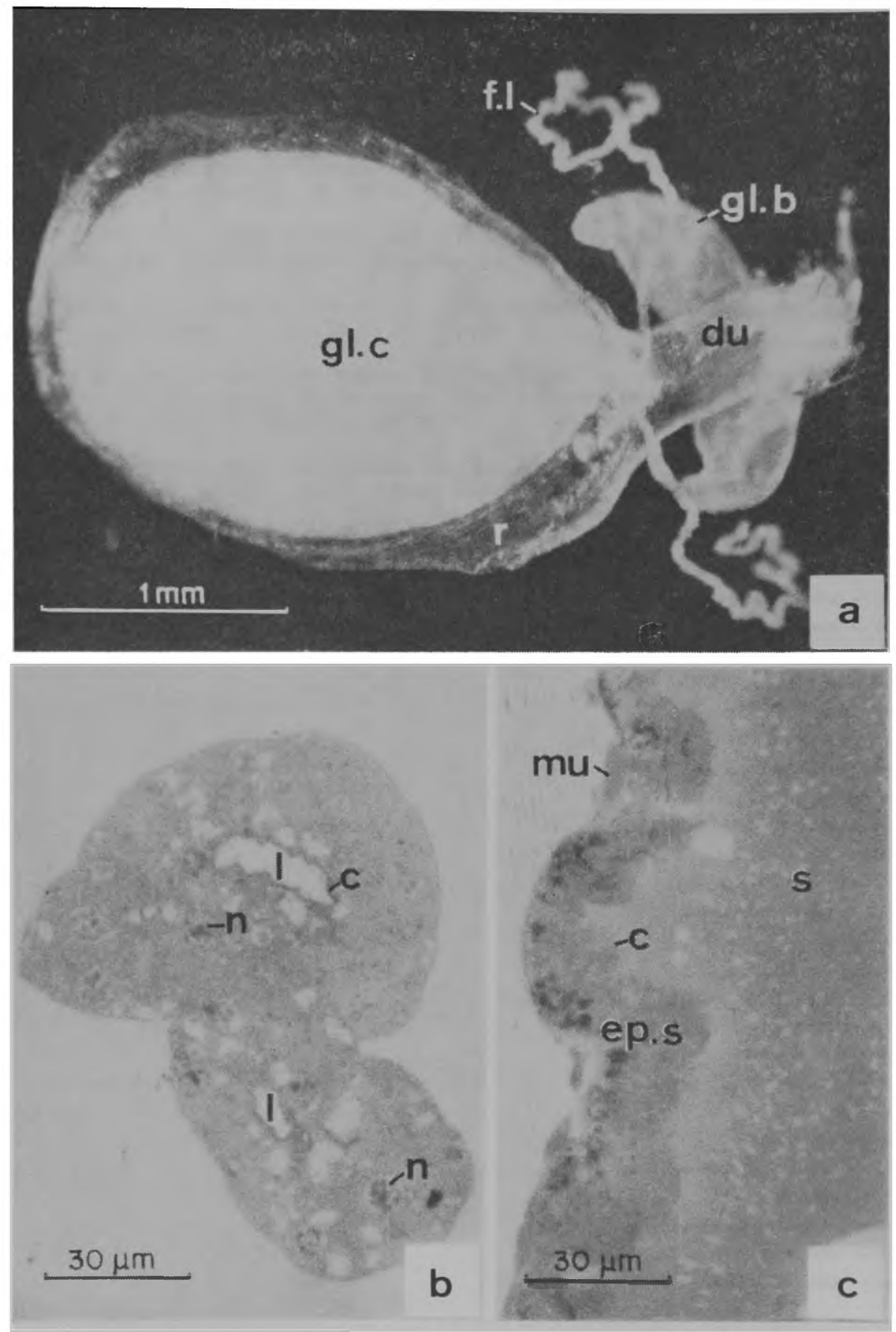

Fig. 1a - Sting glands of Camponotus rufipes.

Fig. 1b - Section of free filament.

Fig. 1c - Section of acid gland. 


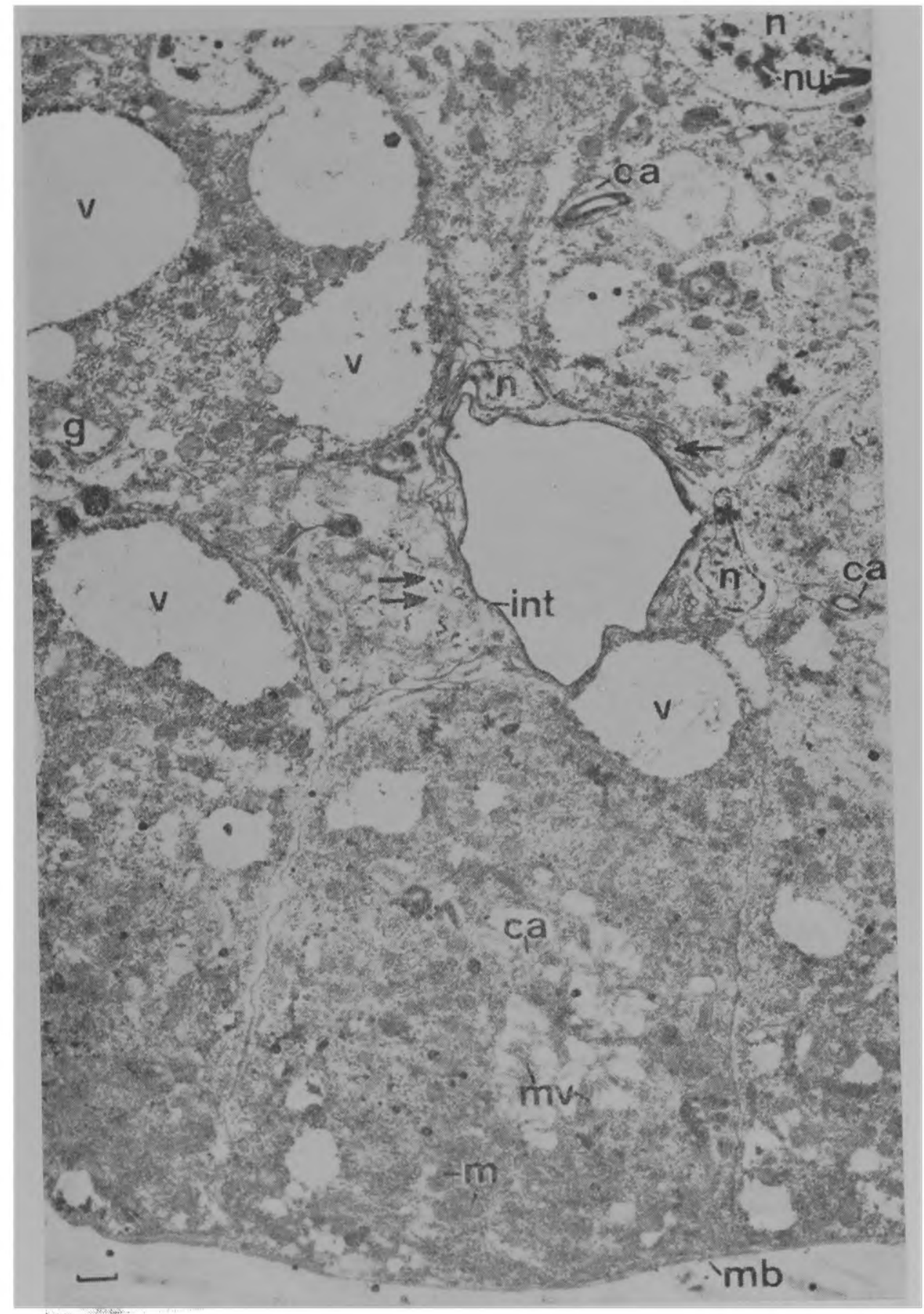

Fig. 2 - Electron micrograph of the free filament. Can be seen intima (int) coating the lumen(l) and the canalicules (ca) going towards the secretory cells. The vacuoles (v) contain probably secretion (s). 


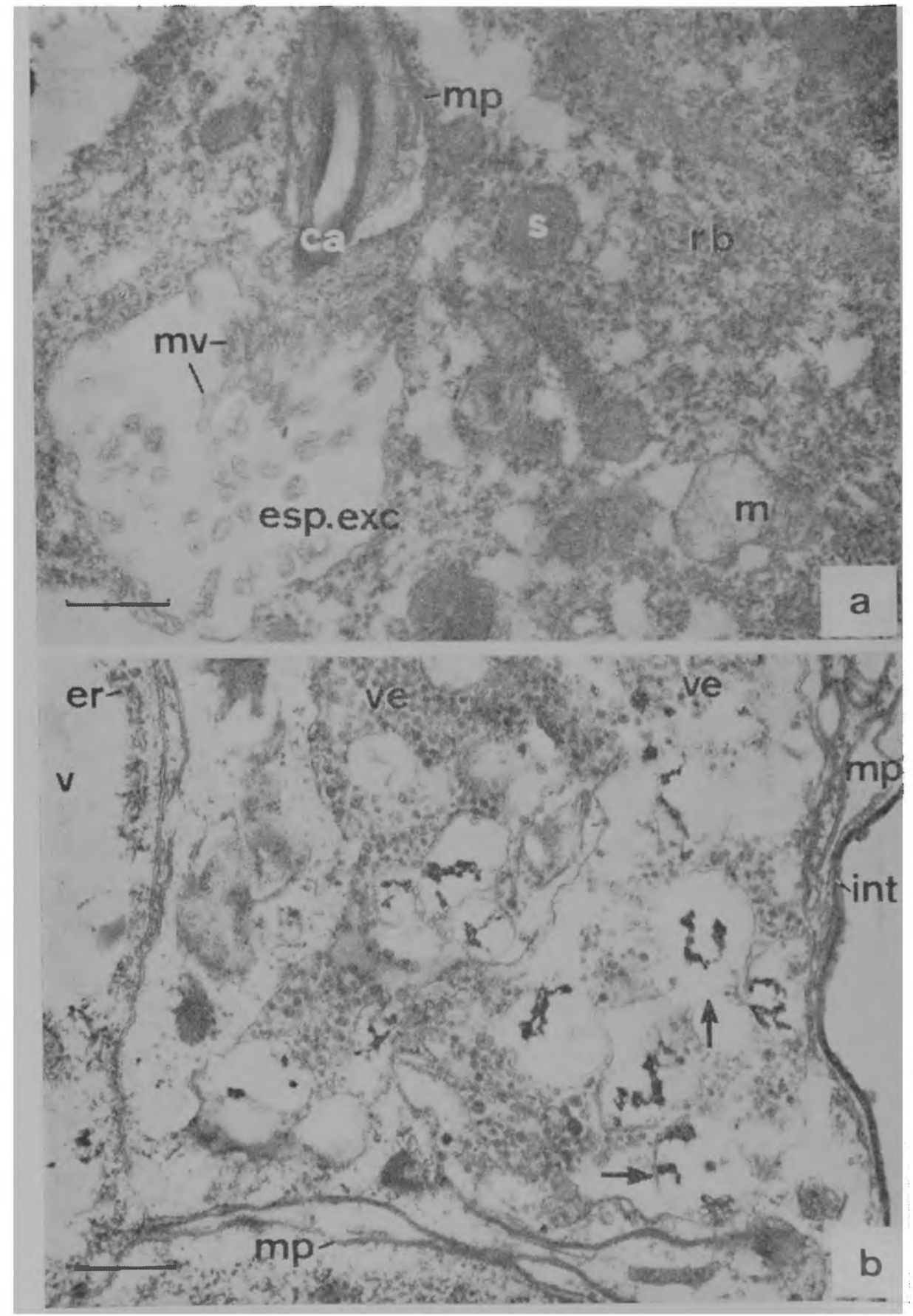

Fig. 3a - Intima (int) arising canalicule (ca), coming from an internal cavity (esp ex) of the secretory cell where sections of microvilli (mv) can be seen.

Fig. 3b - Intima cell showing numerous vesicules (ve) and electron dense material (arrows) inside the vacuoles (v). 


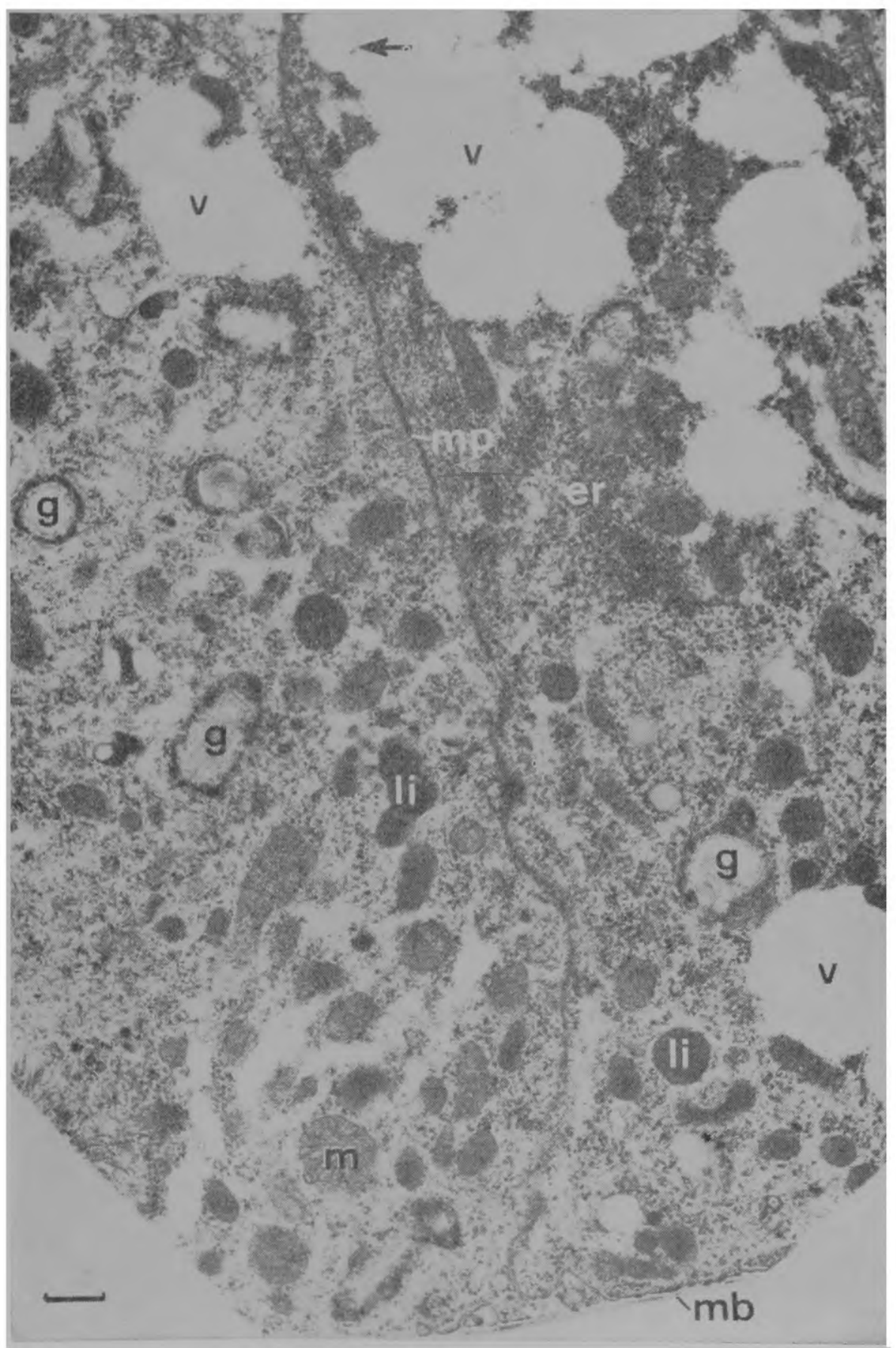

Fig. 4 - Aspect of the free filament secretory cell showing the richness in Golgi (G). The arrows indicate remaining the rest of the membranes from the drops which formed the secretory vacuole (v). 


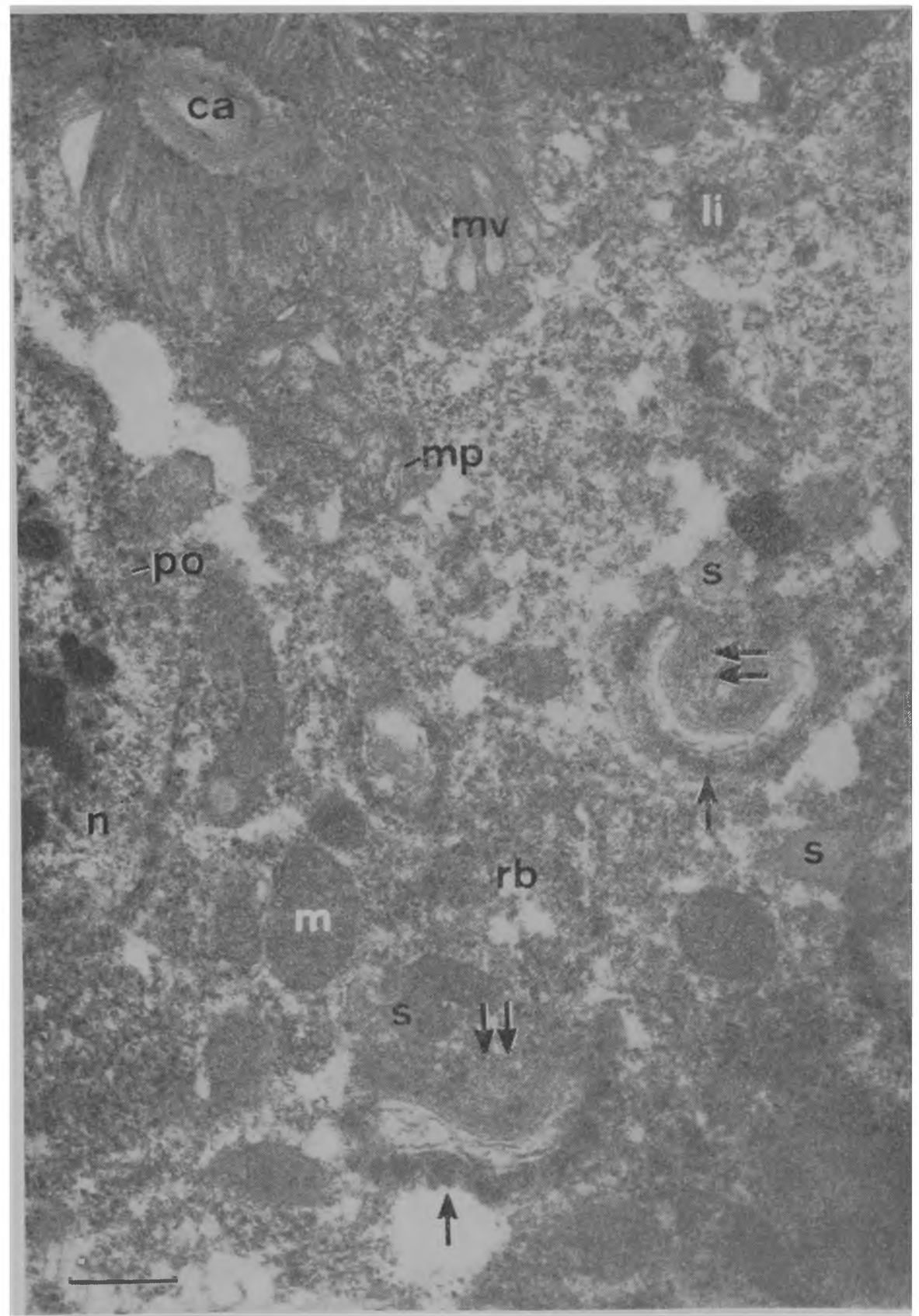

Fig. 5 - Aspect of the Golgi (G) with dense material in the convex face (single arrow) and small vesicles (ve) in the concave face (double arrows). 


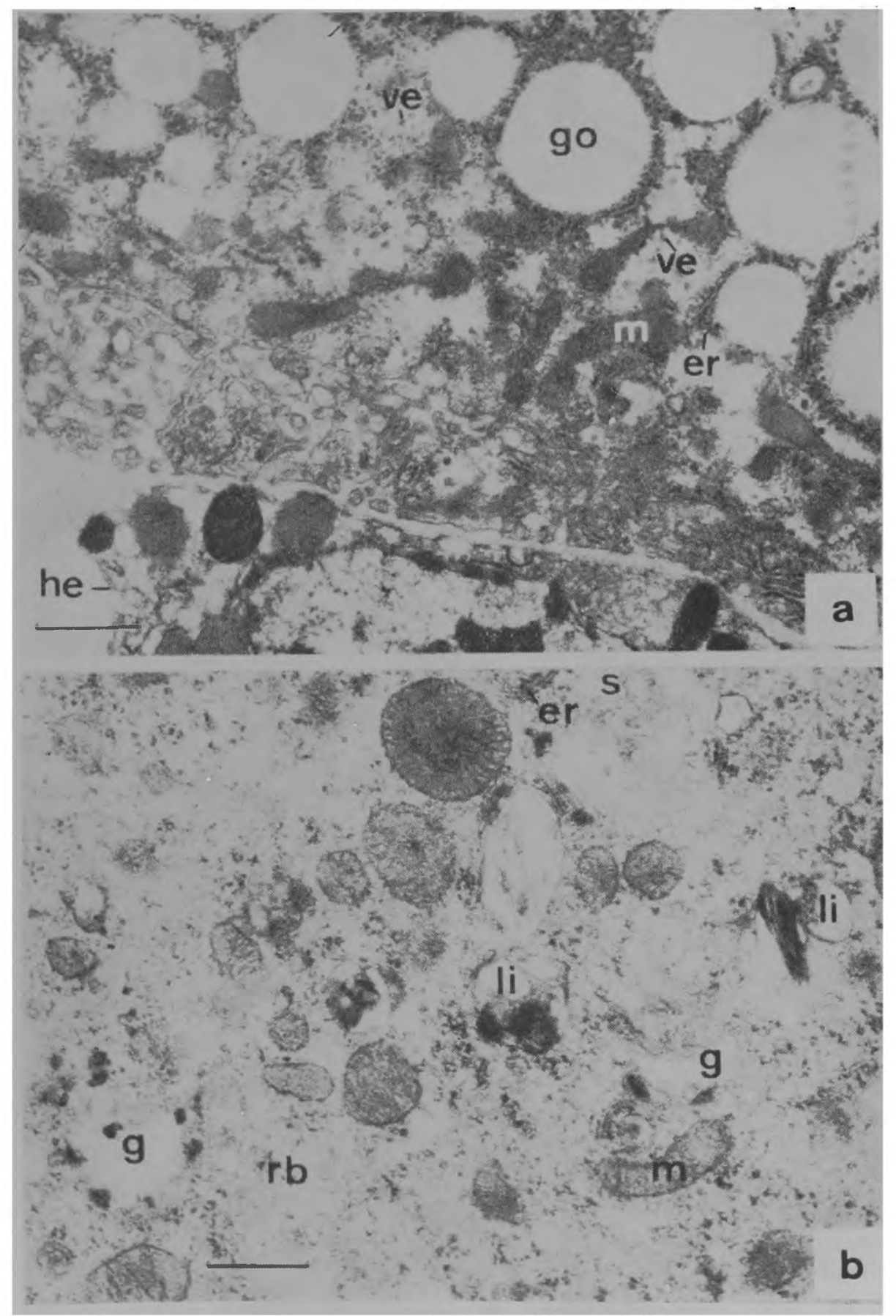

Fig. 6a - Basal portion of the free filament secretory cell, showing drops of secretinn (go) and numerous folds in the plasmic basal membrane (imp).

Fig. 6b - Secondary (li) lysosomes with remainings undigested material in the jnterior. 


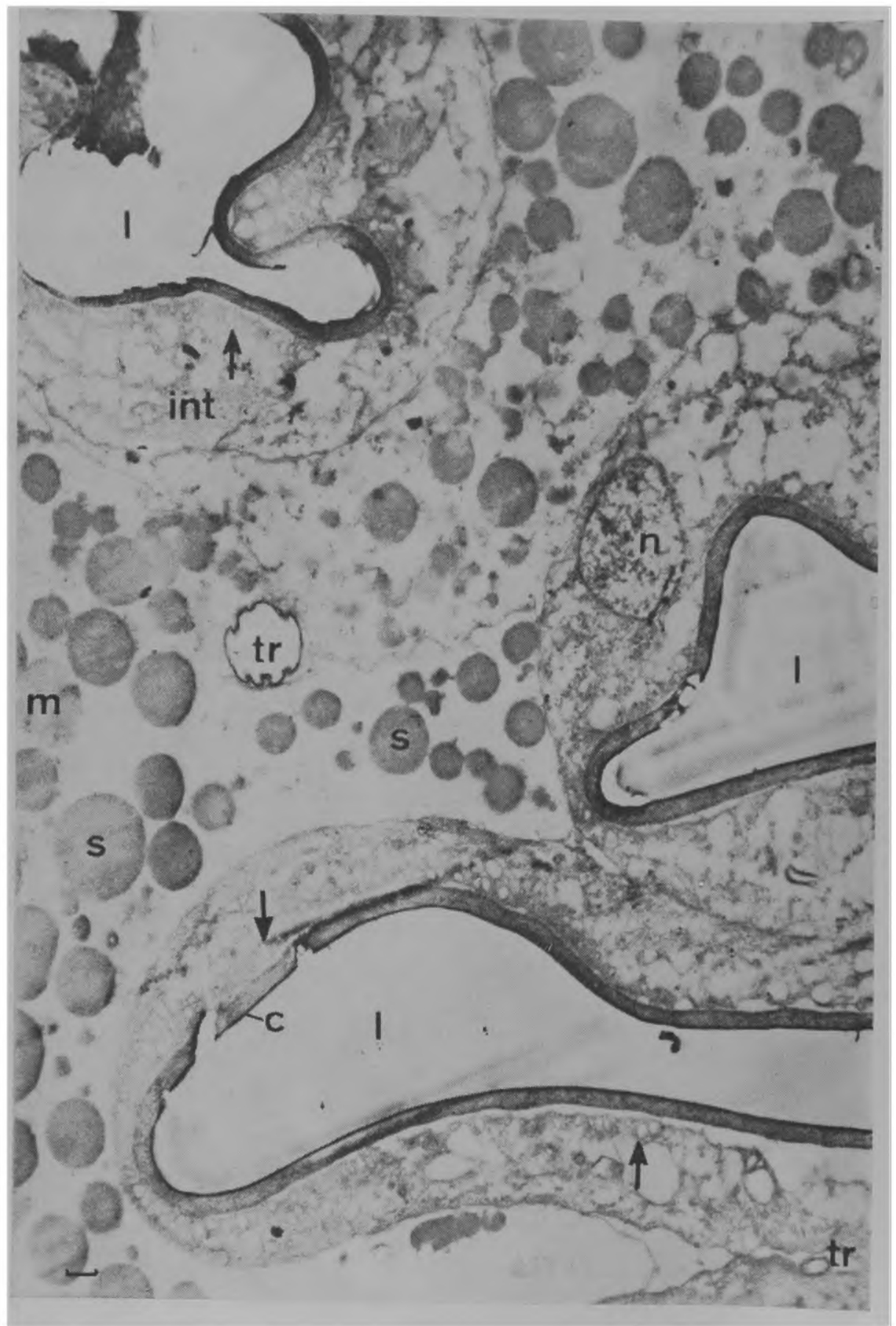

Fig. 7 - Convoluted gland where can be seen the modifications undergone by the secretory cell and the intimal cell. The arrows indicate absorption vesicles under the intimal cuticule. 


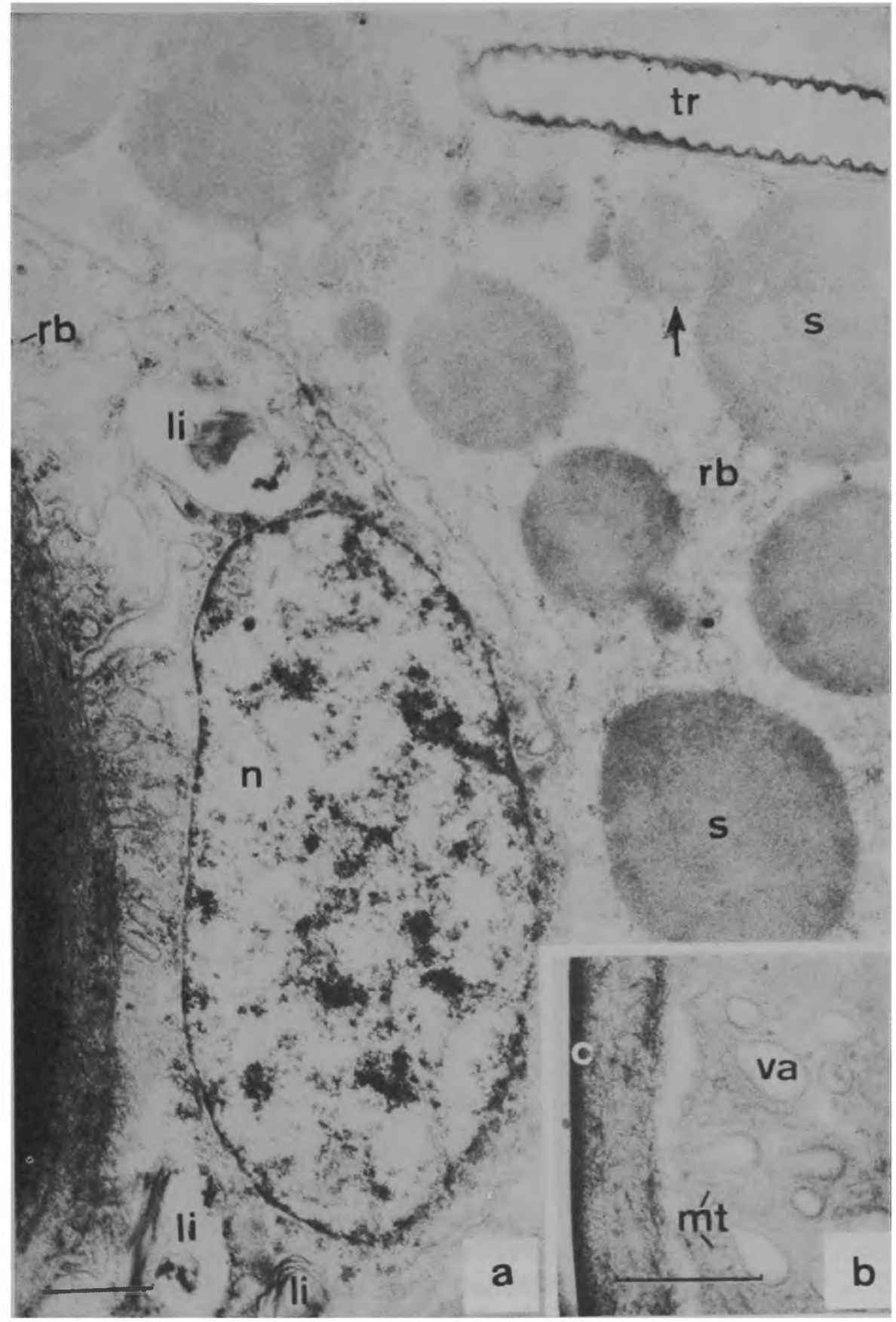

Fig. Ba - Relationship between the secretory and intimal cells in the convoluted gland. Fig. 8b - Detail of vesicles and tubes (tu) present under the intimal cuticle. 


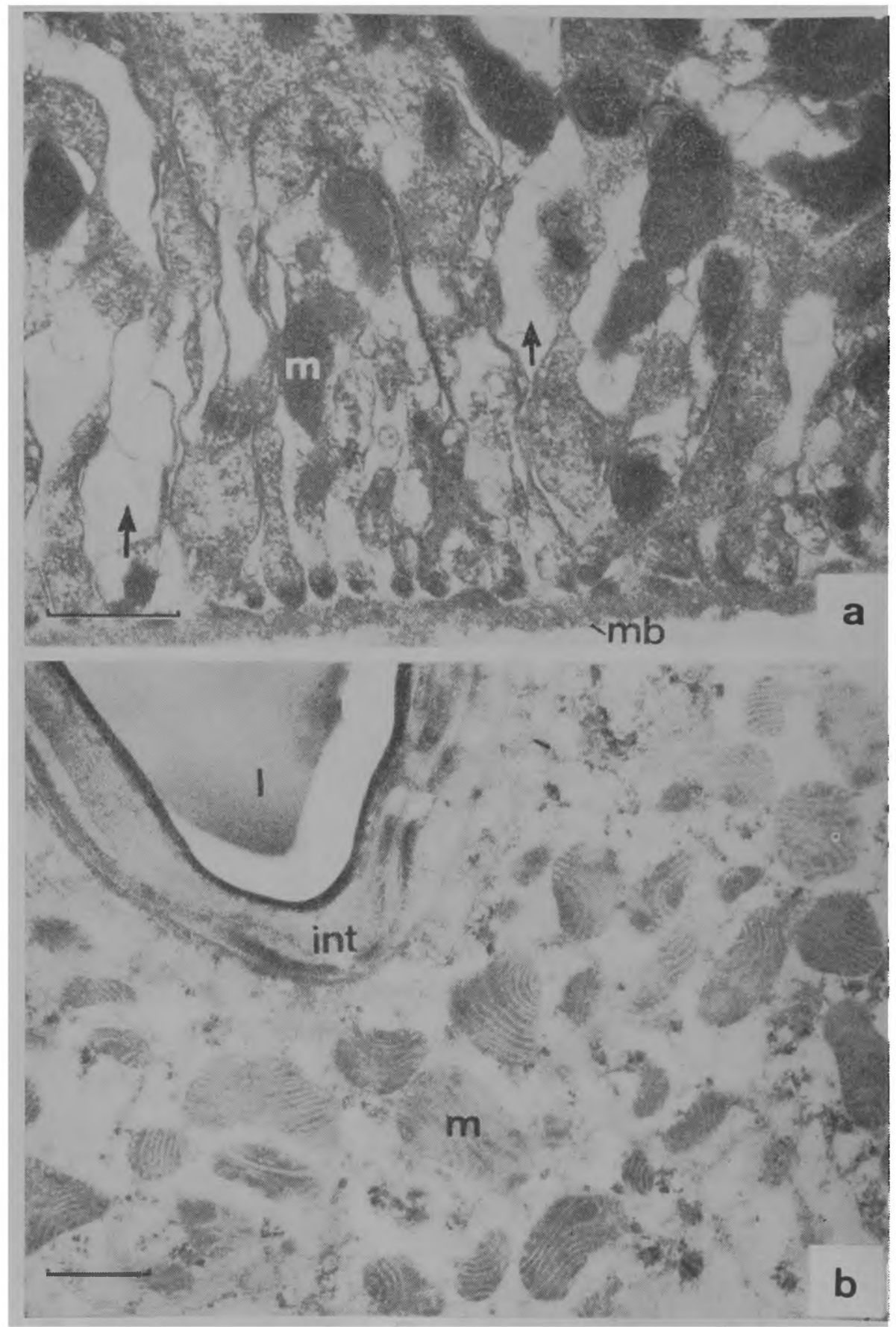

Fig. 9a - Basal portion of the convoluted gland secretory cell. Note the signs of material absorption of the haemolymph with dilatations of the reticulum (arrows).

Fig. 9b - Matrix dense mitochondria $(m)$ in the secretory cell. 


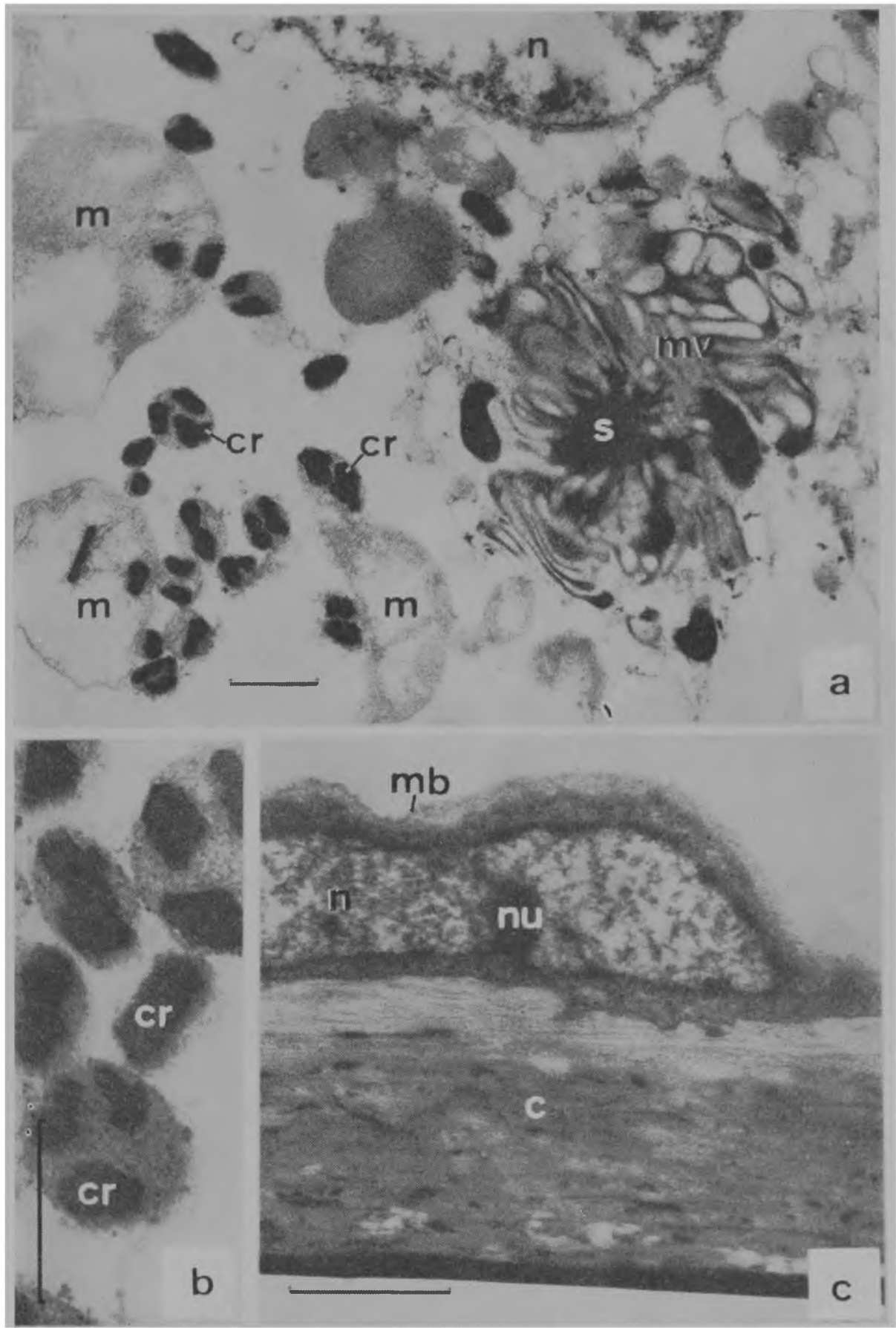

Fig. 10a - Convoluted gland secretory cell with cavity showing microvilli and containing dense material (s) and the mitochondria transformation into crystalline material (cr).

Fig. 10b - Detail of accumulated material in the mitochondrial matrix.

Fig. 10c - Reservoir wall. 


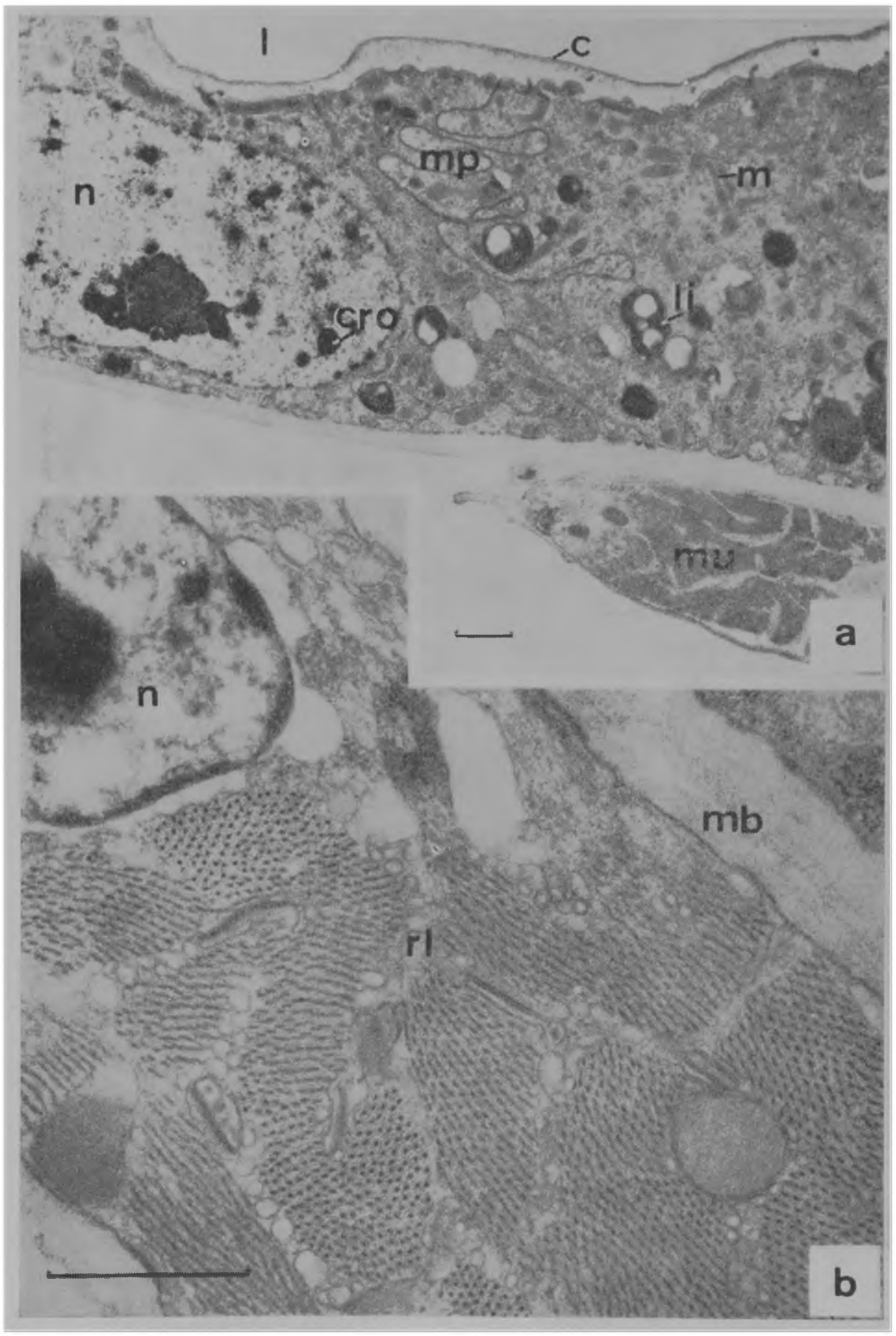

Fig. 11a - Basic gland epithelim (eps).

Fig. 11b - Aspect of the wrapping muscle (mu). 


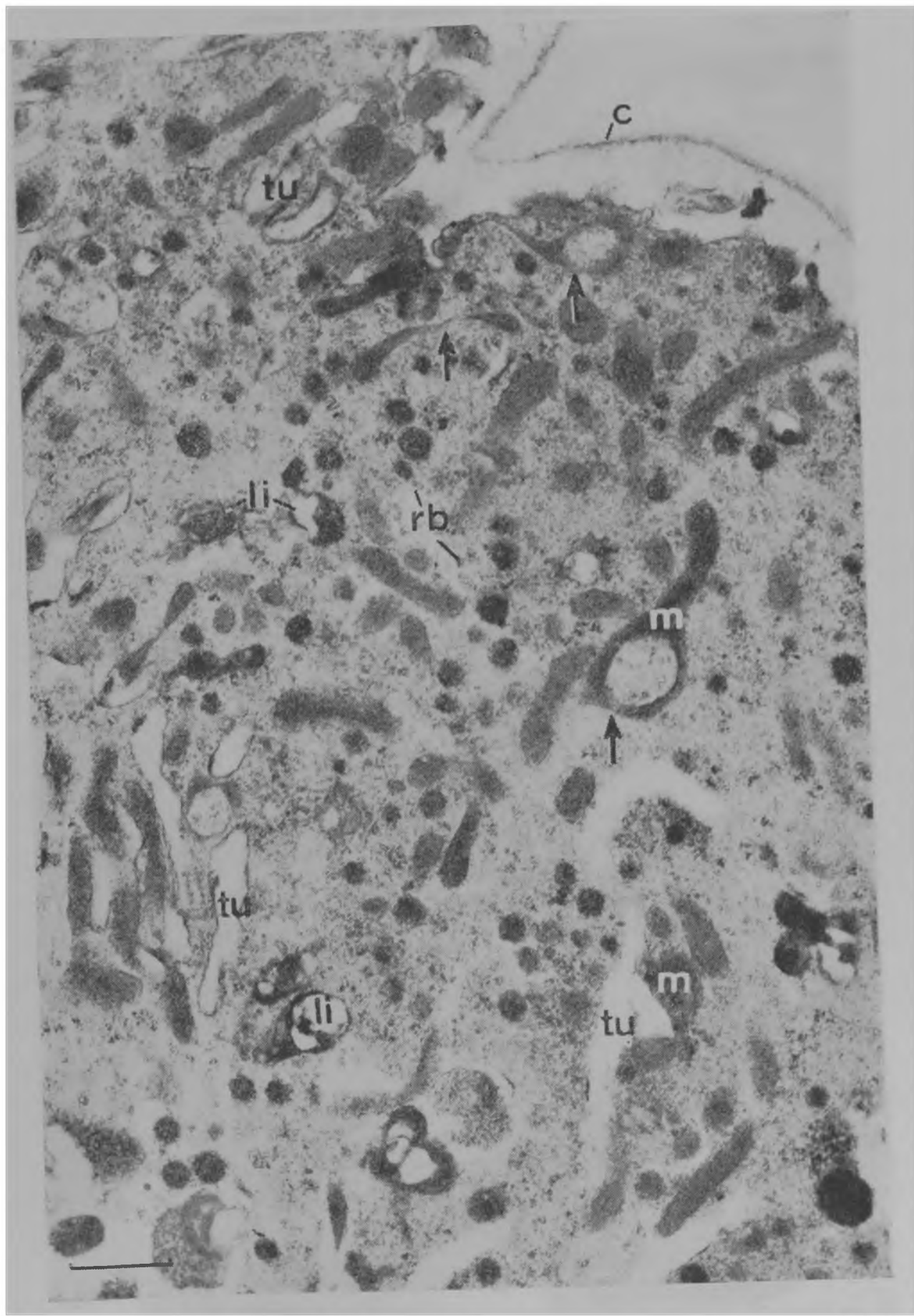

Fig. 12 - Basic gland cell showing great mitochondrial plasticity (arrows) and their association to ducts (tu) originated in the invaginations of the apical plasmic membrane. 


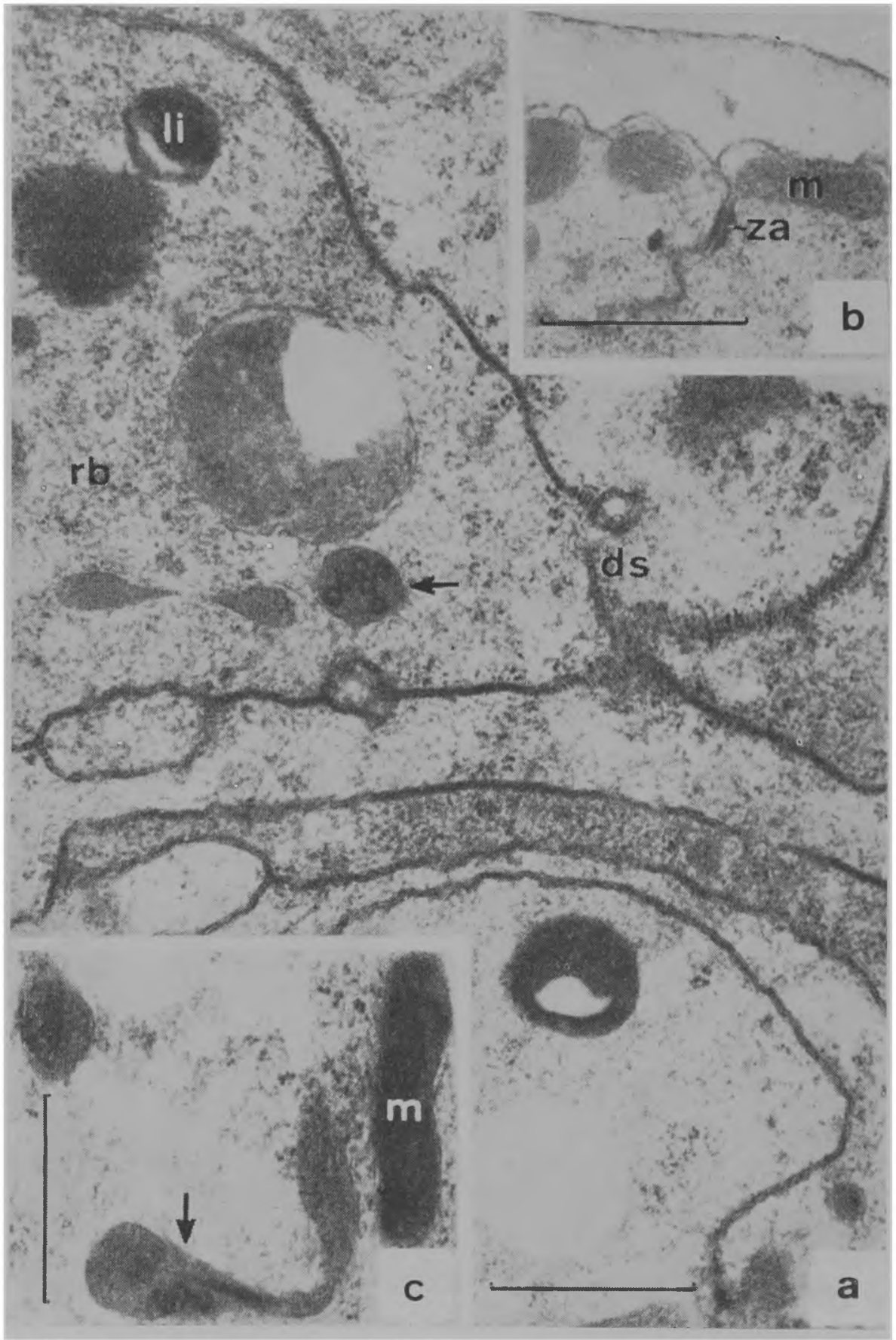

Fig. 13a - Detail of the cellular contacts and mitochondrial transformation (arrows).

Fig. 13b - Mitochondrial transformations with the appearance of membranous wholrs in their interior. 


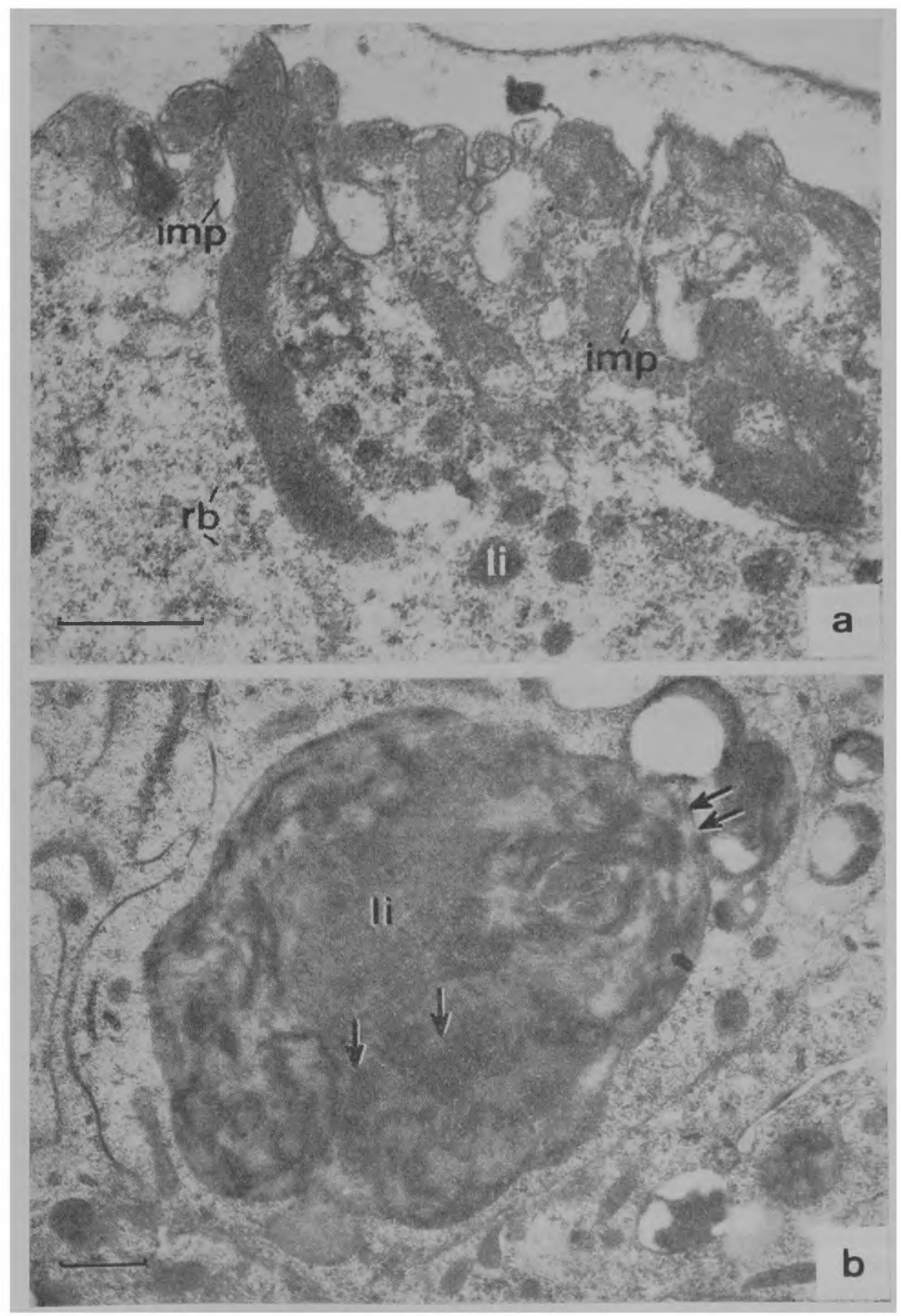

Fig. 14a - Mitochondria perpendicular to the cuticle and associated to invaginations of the plasmic membrane.

Fig. 14b - Residual bodies resultant of the cellular autophagy. The double arrows show a probable fusion and the single crystalline material. 
